\author{
Przemysław KWOLEK ${ }^{1}$ \\ Marek GÓRAL ${ }^{2}$ \\ Anna POZNAŃSKA ${ }^{3}$ \\ Małgorzata WIERZBIŃSKA ${ }^{4}$ \\ Kamil OCHAL ${ }^{5}$
}

\title{
REGENERACJA WARSTW ALUMINIDKOWYCH NA PODŁOŻU NADSTOPÓW NIKLU STOSOWANYCH NA LOPATKI SILNIKÓW LOTNICZYCH
}

\begin{abstract}
$\mathrm{W}$ artykule przedstawiono wybrane metody usuwania dyfuzyjnych warstw aluminidkowych stosowanych do ochrony powierzchni lopatek turbin silników lotniczych przed oddziaływaniem korozji wysokotemperaturowej. Scharakteryzowano opracowane dotychczas chemiczne i elektrochemiczne metody rozpuszczania warstw aluminidkowych. Na podstawie analizy danych literaturowych wytypowano 3 roztwory: kwasu siarkowego(VI) o stężeniu $25 \%$ mas., mieszaninę stężonego kwasu solnego (40\% obj.) i etanolu (60\% obj.) oraz mieszaninę stężonych kwasów ortofosforowego (50\% obj.), octowego (25\% obj.), azotowego ( $25 \%$ obj.). Przeprowadzono badania kinetyki rozpuszczania modelowej warstwy aluminidkowej modyfikowanej cyrkonem na podłożu stopu Inconel 100. Wykazano, że niezależnie od zastosowanych roztworów, rozpuszczanie następuje równomiernie na powierzchni warstwy. Stwierdzono, że największą skutecznością w usuwaniu warstw cechowała się mieszanina kwasów: ortofosforowego, octowego i azotowego, w której rozpuszczenie warstwy aluminidkowej następowało po ok. $80 \mathrm{~min}$.
\end{abstract}

Słowa kluczowe: warstwa aluminidkowa, regeneracja warstw, rozpuszczanie, łopatki turbin, nadstopy, Inconel 100

\section{Wprowadzenie}

Nadstopy niklu są obecnie najpopularniejszym materiałem stosowanym do wytwarzania łopatek wirujących turbiny, pracujących w części gorącej silników lotniczych i energetycznych turbin gazowych. Muszą one spełnić wysokie wymagania dotyczące właściwości wytrzymałościowych w warunkach wysokiej

${ }^{1}$ Przemysław Kwolek, Politechnika Rzeszowska, e-mail: pkwolek@ prz.edu.pl

2 Autor do korespondencji/corresponding author: Marek Góral, Politechnika Rzeszowska, Powstańców Warszawy 12, 35-959 Rzeszów, e-mail: mgoral@prz.edu.pl

3 Anna Poznańska, Politechnika Rzeszowska

${ }^{4}$ Małgorzata Wierzbińska, Politechnika Rzeszowska, e-mail: mwierzb@prz.edu.pl

5 Kamil Ochał, Politechnika Rzeszowska, e-mail: kochal@prz.edu.pl 
temperatury i korozji. W tym celu na ich podłożu wytwarzane są metaliczne warstwy ochronne - typu MCrAlY ( $\mathrm{M}=\mathrm{Ni}$ lub Co) lub $\beta$-NiAl, także powłokowe bariery cieplne TBC (ang. Thermal Barrier Coatings) złożone z tlenków $\mathrm{ZrO}_{2}$ i $\mathrm{Y}_{2} \mathrm{O}_{3}$. Warstwy aluminidkowe o grubości kilkudziesięciu $\mu \mathrm{m}$ są wytwarzane w procesach: kontaktowo-gazowym (ang. pack cementation), gazowym bezkontaktowym (ang. out of pack) lub chemicznego osadzania z fazy gazowej CVD (ang. Chemical Vapour Deposition). Wytworzona warstwa jest złożona z dwóch stref: zewnętrznej - złożonej z kryształów fazy $\beta$-NiAl oraz wewnętrznej - dyfuzyjnej. Podczas eksploatacji na powierzchni warstwy aluminidkowej na łopatce tworzy się zgorzelina złożona z tlenków (aluminium i innych metali), a także spineli (mikroobszar 1., 2. na rys. 1., tab. 1.). Jednocześnie warstwa aluminidkowa ulega zubożeniu w aluminium (mikroobszar 3., 4. na rys. 1., tab. 1.). Ze względów ekonomicznych zużyte łopatki poddaje się procesowi regeneracji. Wymaga on usunięcia warstwy $\beta$-NiAl i wytworzenia nowej. Warstwy aluminidkowe mogą być usuwane $\mathrm{z}$ powierzchni łopatek przez obróbkę strumieniowo-ścierną. Niestety prowadzi ona do zmniejszenia grubości ich ścianek i tym samym pogorszenia właściwości mechanicznych łopatek. Stąd większe znaczenie przy usuwaniu warstw aluminidkowych mają metody chemiczna i elektrochemiczna, które są mniej pracochłonne i w pewnych warunkach umożliwiają usunięcie warstwy bez naruszenia podłoża. Proces roztwarzania prowadzony jest również w przypadku nowych łopatek, gdy wytworzone warstwy aluminidkowe nie spełniają wymagań dotyczących m.in. ich grubości.

Tabela 1. Wyniki analizy składu chemicznego w mikroobszarach przedstawionych na rys. 1 .

Table 1. The results of chemical composition analysis results from areas presented in fig. 1 .

\begin{tabular}{|c|c|c|c|c|c|c|c|c|c|c|c|}
\hline \multirow{2}{*}{ Mikroobszar } & \multicolumn{10}{|c|}{ Zawartość pierwiastków, \% at. } \\
\cline { 2 - 15 } & $\mathrm{O}^{*}$ & $\mathrm{Mg}$ & $\mathrm{Al}$ & $\mathrm{Si}$ & $\mathrm{Ca}$ & $\mathrm{Ti}$ & $\mathrm{Cr}$ & $\mathrm{Fe}$ & $\mathrm{Co}$ & $\mathrm{Ni}$ & $\mathrm{Mo}$ \\
\hline 1 & 49,9 & 1,7 & 23,4 & 2,7 & 0,7 & 3,6 & 3,8 & 3,4 & - & 10,3 & 0,6 \\
\hline 2 & 51,9 & - & 24,3 & 1,4 & - & 3,1 & 8,4 & - & - & 10,1 & 0,8 \\
\hline 3 & - & - & 22,9 & 2,2 & - & 1,8 & 3,3 & - & 3,0 & 65,5 & 1,2 \\
\hline 4 & - & - & 27,7 & 1,8 & - & 1,2 & 3,6 & - & 4,1 & 60,7 & 0,9 \\
\hline
\end{tabular}

* zawartość obliczona na podstawie stechiometrii.

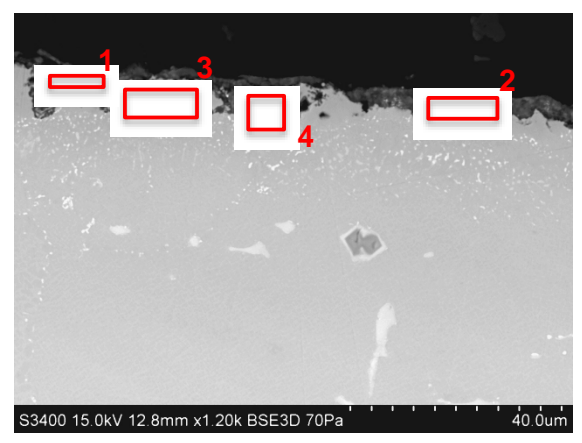

Rys. 1. Mikrostruktura warstwy aluminidkowej na podłożu łopatki ze stopu ZS6K po eksploatacji z zaznaczonymi mikroobszarami analizy składu chemicznego

Fig. 1. Microstructure of aluminide coating on turbine blades made of ZS6K alloy after exploitation with marked areas of chemical composition analysis 


\section{Metody usuwania warstw aluminidkowych}

Proces regeneracji zużytych łopatek wymaga usunięcia $\mathrm{z}$ ich powierzchni zanieczyszczeń zawierających m.in. siarkę, powstających podczas spalania paliwa lotniczego. Stąd łopatki są poddawane wstępnemu trawieniu w wodnym roztworze kwasu octowego o stężeniu $4-6 \%$ mas., w temperaturze $65^{\circ} \mathrm{C}$ w czasie 2-4 h. W tych warunkach warstwa aluminidkowa nie ulega roztwarzaniu [1]. Powłokowa bariera cieplna TBC jest usuwana podczas krótkotrwałej $(t<1 \mathrm{~min})$ obróbki strumieniowo-ściernej łopatki jednocześnie $\mathrm{z}$ warstwą tlenków TGO $\alpha-\mathrm{Al}_{2} \mathrm{O}_{3}$. Używane zwykle ścierniwa to $\mathrm{Al}_{2} \mathrm{O}_{3}, \mathrm{SiO}_{2}$ lub pył stalowy o średnicy ziarn $<150 \mu \mathrm{m}$, a ciśnienie powietrza wynosi 0,1-0,4 MPa [2-5]. Fazy tlenkowe mogą również zostać usunięte z powierzchni łopatki podczas trawienia w roztworze alkalicznym $w$ autoklawie (ciśnienie 0,7-21 $\mathrm{MPa}, T=150-250^{\circ} \mathrm{C}$ ) [6]. Tak przygotowane łopatki są poddawane procesowi trawienia, podczas którego następuje rozpuszczenie warstwy aluminidkowej. Proces usuwania warstwy aluminidkowej powinien się cechować [2]:

- selektywnością - dopuszczalna jest niewielka korozja ogólna podłoża (ubytek masy $<4 \mathrm{mg} / \mathrm{cm}^{2}$ ), na powierzchni łopatki nie powinno być śladów korozji wżerowej, której przebieg może spowodować znaczne pogorszenie właściwości mechanicznych wyrobu,

- dużą kinetyką w temperaturze pokojowej - pozwala to uniknąć nadmiernego parowania odczynników chemicznych i zmniejsza koszty prowadzenia procesu,

- małą toksycznością - stosowane odczynniki chemiczne powinny być bezpieczne do stosowania i łatwe w utylizacji,

- małą podatnością na zaburzenia składu chemicznego roztworu, możliwością jego regeneracji.

Ścisłe spełnienie wspomnianych wymagań jest trudne. $Z$ uwagi na zbliżone właściwości chemiczne materiału podłoża i warstwy aluminidkowej, selektywność może być trudna do osiągnięcia. Odporność chemiczna $\beta$-NiAl wymaga długotrwałego (kilka-, kilkanaście godzin) trawienia w gorących roztworach wodnych kwasów nieorganicznych. Skomplikowana geometria łopatek może prowadzić do niecałkowitego rozpuszczenia warstwy aluminidkowej lub lokalnie intensywnej korozji podłoża. Konieczne może być pracochłonne maskowanie fragmentów powierzchni obrabianych elementów.

Podczas trawienia warstwa aluminidkowa ulega procesowi korozji selektywnej - atomy Al przechodzą do roztworu, pozostaje porowata struktura wzbogacona w Ni. Jej odpadaniu sprzyja intensywne mieszanie roztworu (mechaniczne lub za pomocą ultradźwięków). Całkowite usunięcie pozostałości warstwy aluminidkowej jest osiągane podczas krótkotrwałej (30 s-3 min) obróbki strumieniowo ściernej $[2,7]$. W celu uniknięcia nadmiernych strat metalu i zmniejszenia powierzchni przekroju poprzecznego łopatki, po usunięciu warstwy aluminidkowej 
można pozostawić strefę dyfuzyjną i tak przygotowane łopatki poddać ponownemu procesowi aluminiowania.

Proces rozpuszczania warstw aluminidkowych w większości przypadków jest prowadzony w wodnych roztworach kwasów nieorganicznych zawierających dwa lub więcej składników (oprócz rozpuszczalnika). Wśród roztworów zawierających (oprócz wody) tylko jeden rodzaj kwasu należy wskazać: kwas siarkowy(VI) $\mathrm{H}_{2} \mathrm{SO}_{4}$ o stężeniu $25 \%$ mas. i heksafluorocyrkonowy(IV) $\mathrm{H}_{2} \mathrm{ZrF}_{6}(45 \%$ mas.). Pierwszy z nich umożliwia usunięcie warstwy o grubości $50 \mu \mathrm{m}$ w czasie $t=30 \mathrm{~min}, T=49^{\circ} \mathrm{C}$, przy nieznacznym przebiegu korozji lokalnej $[8,9]$. Podstawową zaletą drugiego jest mniejsza kinetyka roztwarzania i stąd możliwość usunięcia warstwy zewnętrznej - kryształów fazy $\beta$-NiAl i pozostawienia nienaruszonej strefy dyfuzyjnej. Czas potrzebny do usunięcia warstwy aluminidkowej o grubości $50 \mu \mathrm{m}$ w temperaturze $45^{\circ} \mathrm{C}$ to $40 \mathrm{~min}$, po $120 \mathrm{~min}$ stwierdzono tylko nieznaczne roztworzenie warstwy dyfuzyjnej. W podwyższonej temperaturze $\left(70^{\circ} \mathrm{C}\right)$ usunięcie warstwy aluminidkowej nastąpiło po $30 \mathrm{~min}$, natomiast po 120 min - również warstwy dyfuzyjnej [7]. Jednocześnie kwas heksafluorocyrkonowy jest znacznie droższy i bardziej toksyczny w porównaniu z kwasem siarkowym(VI).

Częściej stosowane są mieszaniny dwóch lub więcej kwasów nieorganicznych. Wstępne usunięcie warstwy aluminidkowej z łopatek osiągnięto w mieszaninie kwasów: azotowego(V) $\mathrm{HNO}_{3}\left(33 \%\right.$ mas.) i ortofosforowego(V) $\mathrm{H}_{3} \mathrm{PO}_{4}$ (43\% mas.) o temperaturze $80^{\circ} \mathrm{C}$ po $1-4 \mathrm{~h}$ trawienia. $\mathrm{W}$ drugim etapie trawienie prowadzono w roztworze kwasu solnego o stężeniu 7-14\% mas., $T=70^{\circ} \mathrm{C}$, przez 30-60 min. Zastosowanie $\mathrm{HCl}$ może prowadzić do wystąpienia korozji lokalnej podłoża $[8,9]$. Dlatego zamiast roztworu kwasu solnego można zastosować roztwór alkaliczny o składzie chemicznym: $\mathrm{NaOH} 8-11 \%$ mas., $\mathrm{Na}_{2} \mathrm{CO}_{3} 8-11 \%$ mas., $\mathrm{KMnO}_{4} 4-6 \%$ mas. i temperaturze $T=80^{\circ} \mathrm{C}$. Zadowalające efekty uzyskano po $t=30 \mathrm{~min}$, trawienia [3]. Zastosowanie kwasu heksafluorokrzemowego(IV) znacznie wydłuża czas trawienia. Dla roztworu zawierającego $\mathrm{H}_{2} \mathrm{SiF}_{6}(17 \%$ mas.) i $\mathrm{H}_{3} \mathrm{PO}_{4}(27 \%$ mas.) warstwy aluminidkową i dyfuzyjną usunięto po $13 \mathrm{~h}$ trawienia w temperaturze $70^{\circ} \mathrm{C}[10]$.

Do rozpuszczania warstw aluminidkowych są również używane roztwory zawierające kwas fluorowodorowy HF. Jednak zbyt duże jego stężenie (> 5\% mas.) prowadzi do pasywacji warstwy aluminidkowej - na jej powierzchni tworzy się trudno rozpuszczalny fluorek niklu(II) $\mathrm{NiF}_{2}$, który utrudnia bądź uniemożliwia jej usunięcie. Jednocześnie jony fluorkowe obecne w roztworze mogą wywoływać korozję wżerową podłoża. Dla nadstopów niklu zawierających $>15 \%$ mas. Cr stosowano roztwór o składzie chemicznym: $\mathrm{HF} 2 \%$ mas., $\mathrm{HNO}_{3}$ $8 \%$ mas. Czas trawienia w temperaturze $49-60^{\circ} \mathrm{C}$ wynosił $15-60$ min [2]. Stopy o mniejszej zawartości chromu ulegały w tych warunkach korozji. Stąd zamiast kwasu fluorowodorowego do roztworu $\mathrm{HNO}_{3}$ wprowadzono wodorofluorek amonu $\mathrm{NH}_{4} \mathrm{HF}_{2}$ o stężeniu 1,5\% mas. Dobrą zwilżalność warstwy aluminidkowej 
przez roztwór trawiący zapewnia środek powierzchniowo czynny, np. tlenek etylenu o stężeniu 0,01-0,5\% mas. Czas trawienia to $15-60 \mathrm{~min}$ w roztworze o temperaturze $24^{\circ} \mathrm{C}$ [2]. Te same składniki znajdują się w dostępnym na rynku roztworze ASC 2-N (APV Engineered Coatings) [11]. Dalsze zmniejszenie stężenia jonów fluorkowych $\mathrm{F}^{-}$pozwala usuwać warstwę aluminidkową bez naruszania warstwy dyfuzyjnej. Zastosowano roztwór wodny $\mathrm{NH}_{4} \mathrm{~F}$ o stężeniu $0,027 \%$ mas. i $\mathrm{HNO}_{3} 21 \%$ mas. Czas roztwarzania warstwy o grubości $50 \mu \mathrm{m}$ w temperaturze pokojowej to $30 \mathrm{~min}$ [2].

Stosowane są również roztwory o większej liczbie składników, np. zawierające kwasy ortofosforowy $(\mathrm{V})$, azotowy $(\mathrm{V})$ i octowy $\mathrm{CH}_{3} \mathrm{COOH}$ o stężeniu odpowiednio: 49, 16 i $18 \%$ mas. Stwierdzono, że największy wpływ na kinetykę procesu trawienia ma pierwszy z nich. Warstwa aluminidkowa o grubości $50 \mu \mathrm{m}$ ulega $\mathrm{w}$ nim roztworzeniu w czasie $20 \mathrm{~min}$, zakres temperatury jego pracy to $54-104^{\circ} \mathrm{C}$. Jednocześnie nawet po $20 \mathrm{~h}$ trawienia na powierzchni podłoża nie stwierdzono obecności śladów świadczących o jego korozji międzykrystalicznej. $\mathrm{W}$ celu poprawy warunków bezpieczeństwa pracy zamiast kwasu octowego można zastosować kwas chlorooctowy [12]. Do mieszaniny kwasów nieorganicznych można wprowadzać sole metali o właściwościach utleniających. Usuwanie warstwy aluminidkowej w roztworze o składzie chemicznym: $\mathrm{HNO}_{3} \quad 33-35 \%$ mas, $\mathrm{HCl} 3-4 \%$ mas., $\mathrm{H}_{2} \mathrm{SO}_{4}$ 0,1-2\% mas., $\mathrm{CuSO}_{4}<0,2 \%$ mas., $\mathrm{FeCl}_{3} 0,1-0,3 \%$ mas. trwa kilkadziesiąt godzin w temperaturze pokojowej i wymaga naprzemiennego trawienia (20-24 h) i obróbki strumieniowo ściernej łopatki. Podwyższanie temperatury sprzyja zwiększeniu kinetyki rozpuszczania warstwy aluminidkowej. Jednak dla uniknięcia korozji wżerowej podłoża nie powinna ona przekroczyć $60^{\circ} \mathrm{C}[13,14]$.

Usuwanie warstw aluminidkowych można również prowadzić w roztworach zawierających związki organiczne, m.in. kwasy sulfonowe. Zawierają one grupę sulfonową $\mathrm{SO}_{3} \mathrm{H}$ połączoną z łańcuchem lub pierścieniem węglowodorowym. Są one mocniejszymi kwasami od kwasów karboksylowych, jednocześnie dobrze rozpuszczalnymi w wodzie związkami powierzchniowo czynnymi. Stwierdzono, że do usuwania powłok aluminidkowych nadają się kwasy: metano-, etano-, benzeno-, tolueno- i naftalenosulfonowy. Spośród nich najskuteczniejszy okazał się wodny roztwór kwasu metanosulfonowego o stężeniu 50\% mas. i temperaturze $45^{\circ} \mathrm{C}$. Czas potrzebny do roztworzenia warstwy aluminidkowej o grubości $50 \mu \mathrm{m}$ wynosi 45 min. Niestety w tych warunkach podłoże ulega korozji ogólnej $[8,9]$. Do roztworów kwasu metanosulfonowego można wprowadzać związki nieorganiczne: kwasy i sole. Warstwa aluminidkowa o grubości $50 \mu \mathrm{m}$ ulega roztworzeniu w czasie $4 \mathrm{~h}$, w roztworze wodnym zawierającym kwas metanosulfonowy (38\% mas.) i kwas solny ( $15 \%$ mas.) o temperaturze $50^{\circ} \mathrm{C}$. Stosowane dodatki fosforanu(I) sodu (2\% mas.) lub fluorku aluminium (3\%) nie wpływają znacząco na kinetykę usuwania warstw aluminidkowych [8].

Proces rozpuszczania warstw aluminidkowych można również prowadzić w roztworze zawierającym $19 \%$ mas. $\mathrm{HCl}, 50 \%$ mas. alkoholu etylowego i wody 
zawartej w stężonym roztworze kwasu. Czas trawienia warstwy o grubości $50 \mu \mathrm{m}$ to $45 \mathrm{~min}, T=45^{\circ} \mathrm{C}$. Alkohol etylowy zmniejsza agresywność kwasu względem podłoża metalicznego i poprawia zwilżalność warstwy przez roztwór. Zamiast alkoholu etylowego można zastosować alkohol metylowy lub izopropylowy [8,9]. Dobre wyniki daje zastosowanie naprzemiennego trawienia - najpierw w mieszaninie kwasu solnego i alkoholu etylowego $(t=10 \mathrm{~min})$, następnie $\mathrm{w}$ roztworze kwasu metanosulfonowego $(t=45 \mathrm{~min}) \mathrm{w}$ temperaturze pokojowej $[8,9]$.

Warstwy aluminidkowe można usuwać w procesie elektrolizy. Element z wytworzoną warstwą jest podłączony do dodatniego bieguna źródła prądu stałego i stanowi anodę w procesie elektrolizy. Jako katodę można zastosować np. siatkę z tytanu. Użycie katody odwzorowującej kształt anody zapewnia równomierny rozkład gęstości prądu i równomierne rozpuszczanie warstwy aluminidkowej. Roztwór stosowany do usuwania warstw aluminidkowych składa się z rozpuszczalnika i elektrolitu zapewniającego jego dobre przewodnictwo elektryczne. Rozpuszczalnikiem może być woda lub mieszanina wody z glikolem dietylenowym, gliceryną, węglanem etylenu, glikolem propylenowym lub etylenowym. Elektrolity można podzielić na dwie grupy. W pierwszej występują związki chemiczne o korozyjnym działaniu względem podłoża metalicznego. W nawiasach podano przykładowe ich stężenie w roztworach do elektrochemicznego usuwania warstw aluminidkowych: $\mathrm{HNO}_{3}$ (8\% mas.), $\mathrm{H}_{3} \mathrm{PO}_{4}(8 \%), \mathrm{HCl}(5 \%$ mas.), $\mathrm{CH}_{3} \mathrm{SO}_{3} \mathrm{H}$ (10\% mas.), $\mathrm{NaOH} 10 \%$ (mas.), $\mathrm{NH}_{4} \mathrm{OH}$ (10\% mas.), mieszaniny kwasów, np. azotowego(V) i ortofosforowego. W drugiej grupie występują sole, które nie wykazują działania korozyjnego względem podłoża: $\mathrm{NaCl}(10 \%$ mas.), $\mathrm{MgSO}_{4}$ (10\% mas.), $\mathrm{Na}_{2} \mathrm{CO}_{3}$ (5\% mas.), $\mathrm{NaNO}_{3}$ (10\% mas.), $\mathrm{KCl}$ (10\% mas.), $\mathrm{NH}_{4} \mathrm{Cl}$ (15\% mas.) [15].

Istotne parametry procesu wpływające na kinetykę rozpuszczania warstwy aluminidkowej to odległość pomiędzy anodą i katodą (zwykle od kilku do kilkudziesięciu $\mathrm{cm}$ ), temperatura roztworu (preferowana jest pokojowa) i intensywne jego mieszanie. Proces usuwania warstwy jest prowadzony przy stałym napięciu, np. w zakresie 1,5-2,5 V, natężenie prądu elektrycznego zmniejsza się w czasie. Stwierdzono, że usunięcie warstwy o grubości $50 \mu \mathrm{m} \mathrm{w}$ roztworze wodnym kwasu azotowego i chlorku sodu, ewentualnie kwasu solnego, w temperaturze $24^{\circ} \mathrm{C}$ następuje w czasie 5-6 min $[15,16]$.

\section{Analiza kinetyki procesu usuwania warstw aluminidkowych}

Ustalając skład chemiczny roztworu odpowiedni dla procesu usuwania warstw aluminidkowych, należy uwzględnić nie tylko kinetykę procesu roztwarzania, ale również koszty odczynników chemicznych, aspekty ochrony środowiska i bhp. Roztwory zawierające kwas heksafluorocyrkonowy i heksafluorokrzemowy pozwalają selektywnie usuwać warstwę aluminidkową bez strefy dyfuzyjnej, ale cechują się dużą toksycznością - podobnie roztwory zawierające kwas fluorowodorowy bądź fluorki. Kwas metanosulfonowy jest z kolei znacznie 
droższy w porównaniu z kwasami nieorganicznymi. Stąd na podstawie analizy dostępnej literatury do badań kinetyki roztwarzania warstw aluminidkowych wytypowano 3 roztwory:

1) kwasu siarkowego(VI) (25\% mas.),

2) kwasów: ortofosforowego (49\% mas.), azotowego(V) (16\% mas.) i octowego (18\% mas.),

3) kwasu solnego (19\% mas.) w alkoholu etylowym.

Pozwalają one usunąć warstwę aluminidkową o grubości $50 \mu \mathrm{m}$ w czasie $<1,5 \mathrm{~h}$ w temperaturze $<50^{\circ} \mathrm{C}[8,9,12]$.

$\mathrm{W}$ prowadzonych badaniach własnych procesowi trawienia poddano warstwy aluminidkowe modyfikowane cyrkonem o grubości ok. $36 \mu \mathrm{m}$, wytworzone w niskoaktywnym procesie CVD na podłożu próbek o średnicy $20 \mathrm{~mm}$, ze stopu Inconel 100. Cechowały się one zawartością Al w strefie zewnętrznej, wynoszącą $39 \%$ at. (rys. 2., tab. 2.). Na podstawie ubytku masy określono szybkość roztwarzania warstwy w funkcji czasu (tab. 3.). Stwierdzono, że największą kinetyką roztwarzania warstwy aluminidkowej cechuje się mieszanina kwasów: ortofosforowego, azotowego i octowego. Szybkość roztwarzania warstwy w tym roztworze zmniejsza się z czasem.

Rys. 2. Mikrostruktura warstwy aluminidkowej na podłożu stopu IN 100 przed procesami roztwarzania

Fig. 2. The microstructure of aluminide coating obtained by the CVD method on IN 100 nickel superalloy before dissolution treatment

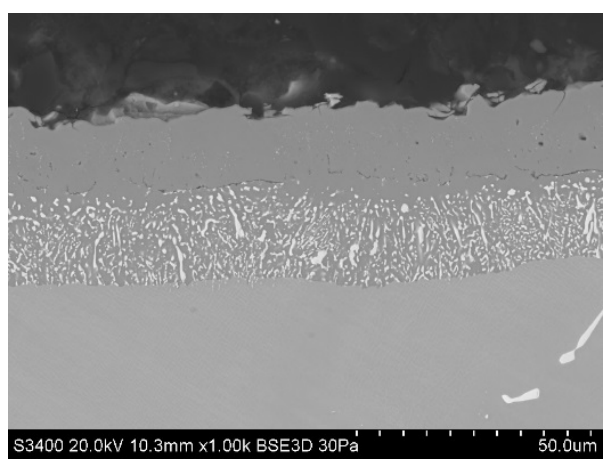

Tabela 2. Wyniki analizy składu chemicznego w mikroobszarach 1-6. na rys. 4.

Table 2. The results of chemical composition analysis results from areas 1-6. presented in fig. 4.

\begin{tabular}{|c|c|c|c|c|c|c|c|c|}
\hline \multirow{2}{*}{ Mikroobszar } & \multicolumn{7}{|c|}{ Zawartość pierwiastków, \% at. } \\
\cline { 2 - 10 } & $\mathrm{Al}$ & $\mathrm{Ti}$ & $\mathrm{Cr}$ & $\mathrm{Co}$ & $\mathrm{Ni}$ & $\mathrm{Zr}$ & $\mathrm{Mo}$ & $\mathrm{W}$ \\
\hline 1 & 37,6 & 0,4 & 3,3 & 6,5 & 51,2 & 0,4 & & 0,7 \\
\hline 2 & 26,0 & 1,0 & 9,7 & 9,7 & 48,0 & & 0,6 & 5,0 \\
\hline 3 & 37,7 & 0,4 & 3,6 & 6,5 & 51,1 & 0,1 & & 0,5 \\
\hline 4 & 25,8 & 1,4 & 9,6 & 9,0 & 50,0 & 0,1 & 0,8 & 3,4 \\
\hline 5 & 35,7 & 0,6 & 4,5 & 7,5 & 51,2 & & & 0,6 \\
\hline 6 & 24,5 & 2,4 & 9,8 & 9,7 & 48,8 & 0,5 & 0,7 & 3,6 \\
\hline
\end{tabular}


Tabela 3. Szybkość roztwarzania warstw aluminidkowych

Table 3. Kinetics of the dissolution process of aluminide coating

\begin{tabular}{|l|c|c|}
\hline \multicolumn{1}{|c|}{ Skład roztworu rozpuszczającego } & $\begin{array}{c}\text { Czas } \\
\text { procesu, } \\
\text { min }\end{array}$ & $\begin{array}{c}\text { Szybkość } \\
\text { roztwarzania, } \\
\mathrm{mg} \cdot \mathrm{cm}^{-2} \cdot \mathrm{h}^{-1}\end{array}$ \\
\hline \multirow{2}{*}{$\mathrm{H}_{2} \mathrm{SO}_{4}(25 \%$ mas.) } & 10 & 1,36 \\
\cline { 2 - 3 } & 15 & 1,96 \\
\hline \multirow{2}{*}{$\mathrm{HCl}\left(19 \%\right.$ mas.), $\mathrm{C}_{2} \mathrm{H}_{5} \mathrm{OH}(50 \%$ mas.) } & 32 & 1,96 \\
\hline \multirow{3}{*}{$\mathrm{H}_{3} \mathrm{PO}_{4}$ (49\% mas.), $\mathrm{CH}_{3} \mathrm{COOH}\left(18 \%\right.$ mas.), $\mathrm{HNO}_{3}(16 \%$ mas.) } & 16 & 0,72 \\
\cline { 2 - 3 } & 30 & 0,73 \\
\cline { 2 - 3 } & 45 & 0,67 \\
\cline { 2 - 3 } & 20 & 14,90 \\
\cline { 2 - 3 } & 80 & 14,57 \\
\hline
\end{tabular}

Badania mikroskopowe warstwy aluminidkowej rozpuszczanej w roztworze kwasu siarkowego(VI) o stężeniu $25 \%$ mas. wykazały mały stopień jej usunięcia (rys. 3.). Zmierzona grubość warstwy była praktycznie taka sama jak przed
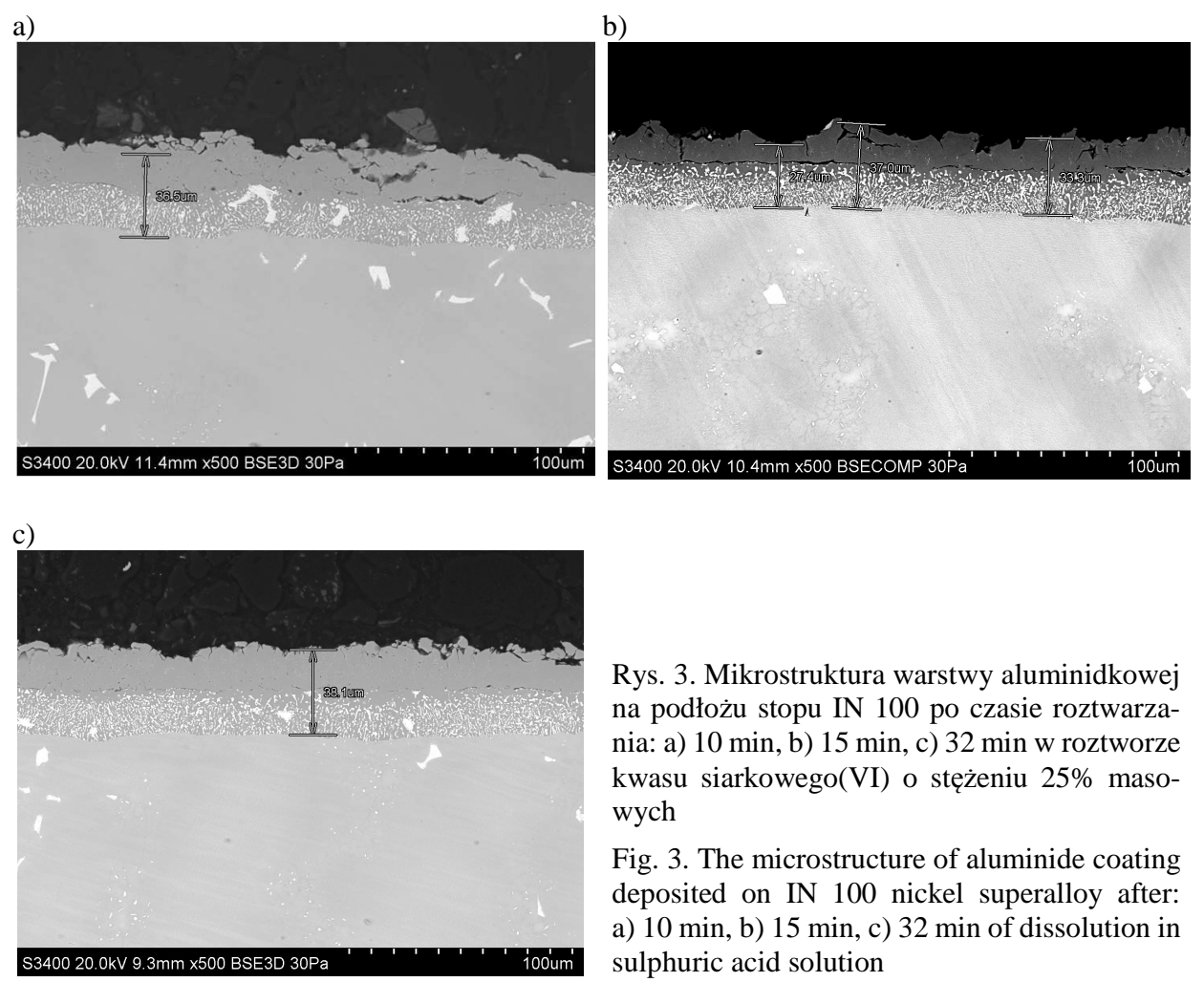

Rys. 3. Mikrostruktura warstwy aluminidkowej na podłożu stopu IN 100 po czasie roztwarzania: a) $10 \mathrm{~min}$, b) $15 \mathrm{~min}$, c) $32 \mathrm{~min}$ w roztworze kwasu siarkowego(VI) o stężeniu $25 \%$ masowych

Fig. 3. The microstructure of aluminide coating deposited on IN 100 nickel superalloy after: a) $10 \mathrm{~min}$, b) $15 \mathrm{~min}, \mathrm{c}) 32 \mathrm{~min}$ of dissolution in sulphuric acid solution 
rozpuszczaniem i wynosiła $36-38 \mu \mathrm{m}$. Nie stwierdzono również różnic w zawartości $\mathrm{Al} \mathrm{w}$ strefie zewnętrznej warstwy - wynosiła ona ok. $37 \%$ at. - niezależnie od czasu trawienia. Wyniki badań wskazują, że rozpuszczenie strefy zewnętrznej warstwy aluminidkowej z użyciem tego roztworu trwałoby wiele godzin.

Silniejsze oddziaływanie na warstwę aluminidkową stwierdzono w przypadku użycia roztworu stężonego kwasu solnego w etanolu. Po 16 min zanurzania w roztworze stwierdzono lokalne rozpuszczenie warstwy i zmniejszenie jej grubości nawet do ok. $25 \mu \mathrm{m}$ (rys. 4a). Po 30 min procesu usuwania również stwierdzono lokalne ubytki w warstwie, a także obecność licznych pęknięć (rys. 4b). Podobnie po 45 min zanurzania nastąpiło znacznie silniejsze roztworzenie obszaru zewnętrznej strefy złożonej z kryształów fazy NiAl (rys. 4c). Wyniki analizy składu chemicznego w mikroobszarach 1., 3. i 5. (rys. 4a-c, tab. 4.) wykazały minimalny spadek zawartości aluminium w zewnętrznej strefie warstwy aluminidkowej do ok. 36-37\% at. Jednocześnie nie stwierdzono znaczących różnic w zawartości pierwiastków w wewnętrznej strefie dyfuzyjnej (mikroobszary 2., 4., 6., rys. 4a-c, tab. 4.).

a)

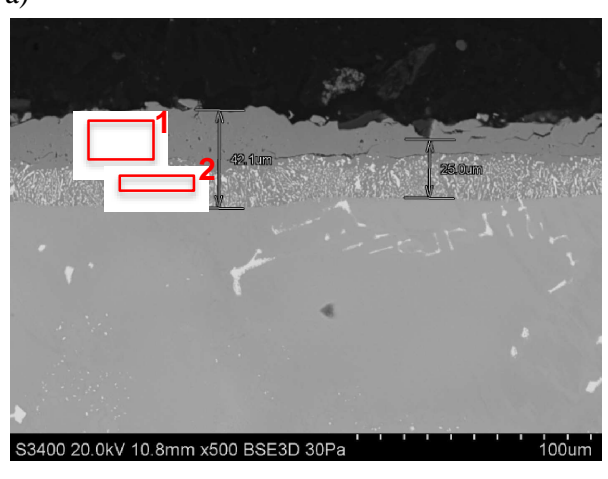

c)

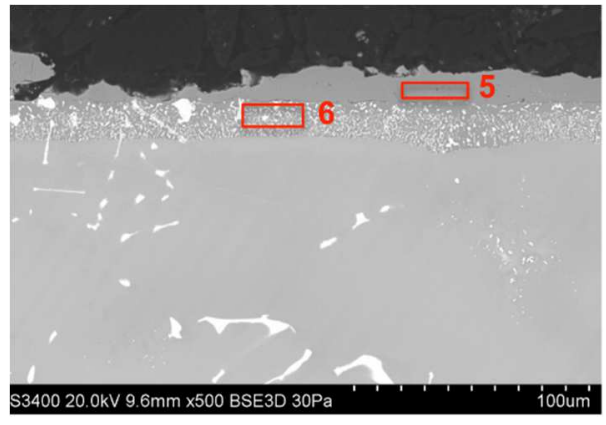

b)

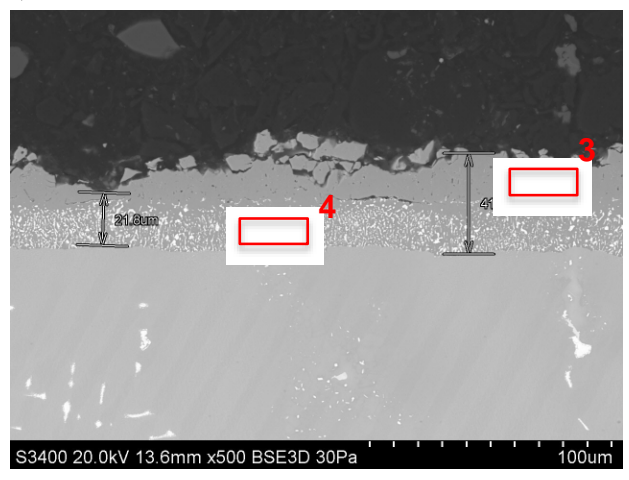

Rys. 4. Mikrostruktura warstwy aluminidkowej na podłożu stopu IN 100 po czasie roztwarzania: a) $16 \mathrm{~min}$, b) $30 \mathrm{~min}$, c) $45 \mathrm{~min} \mathrm{w}$ roztworze stężonego kwasu solnego (40\% obj.) i etanolu (60\% obj.), 1-6 mikroobszary analizy składu chemicznego

Fig. 4. The microstructure of aluminide coating deposited on IN 100 nickel superalloy after: a) $160 \mathrm{~min}$, b) $30 \mathrm{~min}$, c) $45 \mathrm{~min}$ of dissolution in hydrochloric acid and ethanol 
Tabela. 4. Wyniki analizy składu chemicznego w mikroobszarach 1-7. na rys. 5.

Table 4. The results of chemical composition analysis results from areas 1-7. presented in fig. 5.

\begin{tabular}{|c|c|c|c|c|c|c|c|c|c|}
\hline \multirow{2}{*}{ Mikroobszar } & \multicolumn{8}{|c|}{ Zawartość pierwiastków, \% at. } \\
\cline { 2 - 12 } & $\mathrm{Al}$ & $\mathrm{Ti}$ & $\mathrm{Cr}$ & $\mathrm{Co}$ & $\mathrm{Ni}$ & $\mathrm{Zr}$ & $\mathrm{Mo}$ & $\mathrm{W}$ & $\mathrm{Si}$ \\
\hline 1 & 35,8 & 0,5 & 4,3 & 7,2 & 51,5 & 0,3 & & 0,5 & \\
\hline 2 & 26,4 & 1,1 & 10,2 & 9,8 & 46,8 & 0,1 & 0,6 & 5,0 & \\
\hline 3 & 35,8 & 0,5 & 4,9 & 7,2 & 50,9 & 0,1 & & 0,6 & \\
\hline 4 & 25,9 & 1,0 & 10,5 & 10,2 & 46,5 & 0,2 & 0,6 & 5,2 & \\
\hline 5 & 34,7 & 0,6 & 5,0 & 7,9 & 51,2 & & & 0,6 & \\
\hline 6 & 26,2 & 1,2 & 10,1 & 9,3 & 48,4 & 0,1 & 0,5 & 4,3 & \\
\hline 7 & 24,2 & 1,9 & 8,8 & 8,4 & 45,0 & & 0,5 & 2,8 & 8,4 \\
\hline
\end{tabular}

a)

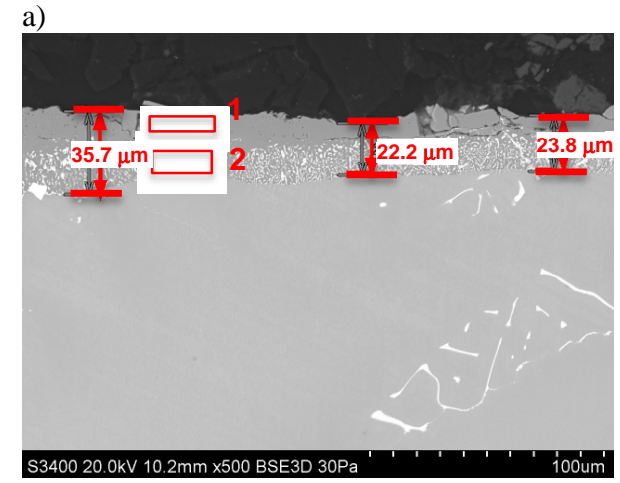

c)

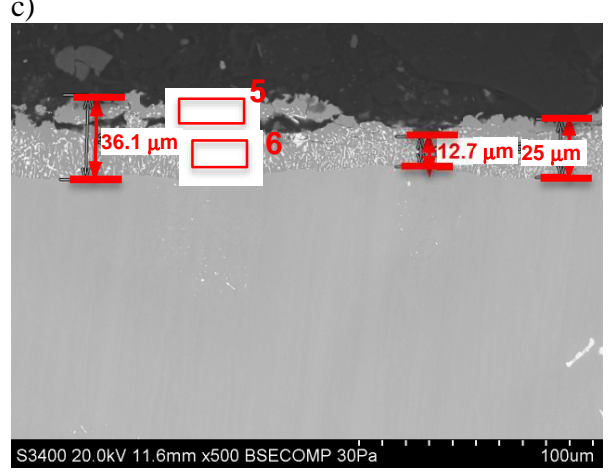

b)

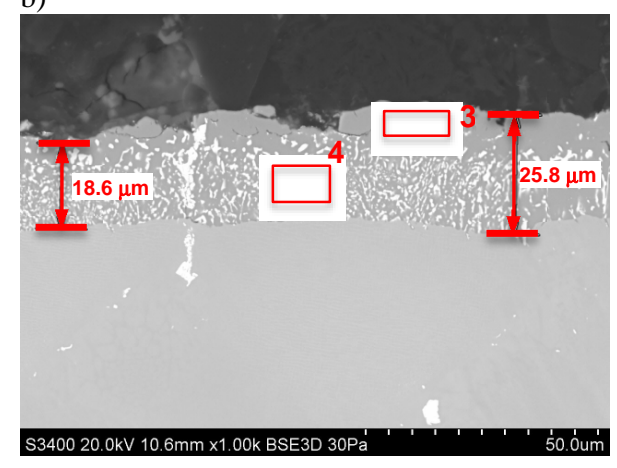

d)

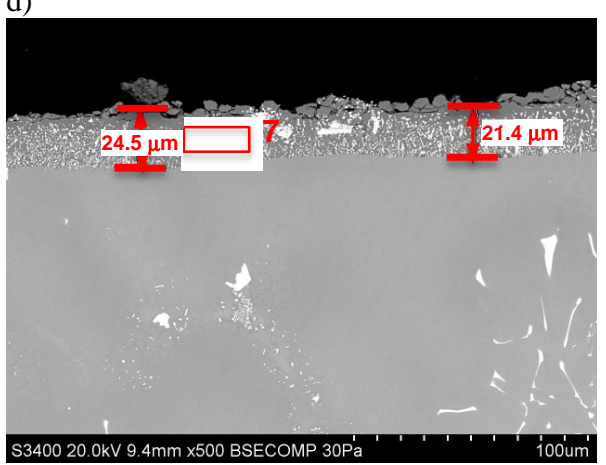

Rys. 5. Mikrostruktura warstwy aluminidkowej na podłożu stopu Inconel 100 po czasie roztwarzania: a) $20 \mathrm{~min}$, b) $30 \mathrm{~min}$, c) $60 \mathrm{~min}$, d) $80 \mathrm{~min} \mathrm{w}$ mieszaninie stężonych kwasów ortofosforowego ( $50 \%$ obj.), octowego ( $25 \%$ obj.), azotowego (25\% obj.), 1-7 mikroobszary analizy składu chemicznego

Fig. 5. The microstructure of aluminide coating deposited on IN 100 nickel superalloy after: a) $20 \mathrm{~min}$, b) $30 \mathrm{~min}$, c) $60 \mathrm{~min}$, d) $80 \mathrm{~min}$ of dissolution in orthophosphoric, acetic and nitride acid solutions 
W dalszych próbach z użyciem mieszaniny stężonych kwasów: ortofosforowego (49\% mas.), octowego (18\% mas.), azotowego (16\% mas.) wydłużono czas rozpuszczania do $80 \mathrm{~min}$. Po 20 min zanurzania w mieszaninie stwierdzono niewielkie, lokalne ubytki w zewnętrznej strefie warstwy aluminidkowej i spadek grubości do 22-24 $\mu \mathrm{m}$ (rys. 5a). Zwiększenie czasu trawienia do 30 min skutkowało lokalnym całkowitym zanikiem zewnętrznej strefy warstwy aluminidkowej (rys. 5b). Stwierdzono również zmniejszenie całkowitej grubości warstwy aluminidkowej do ok. $25 \mu \mathrm{m}$. Wydłużenie czasu zanurzania w roztworze do $60 \mathrm{~min}$ skutkowało prawie całkowitym zanikiem strefy zewnętrznej warstwy aluminidkowej (rys. 5c). Jednocześnie w jej mikrostrukturze były widoczne lokalne pęknięcia pozostałości strefy zewnętrznej. Grubość warstwy po 60 min trawienia mieściła się w zakresie ok. 12-25 $\mu \mathrm{m}$. Dalsze wydłużenie czasu trawienia do 80 min skutkowało całkowitym usunięciem zewnętrznej strefy dyfuzyjnej warstwy aluminidkowej (rys. 5d) i zmniejszeniem jej całkowitej grubości do ok. 20-25 $\mu \mathrm{m}$. Przeprowadzona analiza składu chemicznego wykazała niewielki spadek zawartości $\mathrm{Al}$ w pozostałościach zewnętrznej strefy warstwy aluminidkowej do $<35 \%$ at. po trawieniu w czasie 30-60 min. Ze względu na praktycznie całkowite usunięcie strefy zewnętrznej po $80 \mathrm{~min}$ procesu nie przeprowadzono analizy jej składu chemicznego. W strefie wewnętrznej warstwy aluminidkowej zawartość poszczególnych pierwiastków nie ulegała zmianie, a czas procesu trawienia nie miał na to wpływu.

\section{Podsumowanie}

Analiza wyników prób trawienia z użyciem wybranych roztworów jednoznacznie wskazuje, że czas niezbędny do całkowitego usunięcia zewnętrznej strefy dyfuzyjnej warstwy aluminidkowej wynosi > 60 min. Wśród stosowanych odczynników mieszanina kwasów: ortofosforowego, octowego i azotowego wykazała się największą skutecznością w roztwarzaniu zewnętrznej strefy warstwy aluminidkowej, złożonej z kryształów fazy NiAl. Niezależnie od zastosowanych roztworów, proces trawienia następuje równomiernie na powierzchni warstwy. Nie stwierdzono zmniejszenia zawartości głównego składnika strefy zewnętrznej - aluminium - po różnym czasie trawienia. W rzeczywistych warunkach produkcyjnych w procesie regeneracji łopatek turbin po eksploatacji jest niezbędne usunięcie nie tylko pozostałości warstwy aluminidkowej, ale również produktów korozji, m.in. tlenków. Wskazuje to na konieczność sprawdzenia skuteczności odczynników trawiących do usuwania warstwy z łopatek po eksploatacji.

Badania realizowano w ramach zadania 9., pt. Rozwój nowych żaroodpornych powtok ochronnych elementów turbiny projektu INNOLOT/I/7/NCBR/2013 „Zaawansowane techniki wytwarzania zespołu turbiny napędowej” INNOLOT TED finansowanego przez Narodowe Centrum Badań i Rozwoju oraz Europejskiego Funduszu Rozwoju Regionalnego. 


\section{Literatura}

[1] Rosenzweig M.A., Conner J.A., Bowden J.H.J.: Method of removing hot corrosion products from a diffusion aluminide coating, US patent $\mathrm{nr} 6,174,380 \mathrm{~B} 1$ (2001), http://www.google.com/patents/US6174380\%5Cnhttp://patentimages.storage.goog leapis.com/pdfs/US6174380.pdf.

[2] Baldi A.L.: Process of stripping aluminide coating from cobalt and nickel base alloys, US patent $\mathrm{nr}$ 3, 622, 391 (1971).

[3] Grisik J.J., Ellis A.J.: United States Patent, 3, 833, 414 (1974).

[4] Lee J.W., Voehringer C.: Method of remanufacturing turbine vane clusters for gas turbine engines, US patent nr 4, 176, 433, (1979).

[5] Gupta B.K., Grady R.W., Garcia A.F.: Repair method for tbc coated turbine components, US 2010/0126014 (2010).

[6] Rosenzweig M.A., Conner J.A., Bowden J.H.J.: Method of removing hot corrosion products from a diffusion aluminide coating, US patent nr 6, 174, 380 B1 (2001).

[7] Kool L.B., Ruud J.A.: Process for partial stripping of diffusion aluminide coatings from metal substrates and related compositions, US patent $\mathrm{nr}$ 6, 758, 914 B2 (2004).

[8] Macdonald L.S., Sangeeta D., Rosenzweig M.A.: Method for removing an aluminide coating from a substrate, US patent $\mathrm{nr}$ 6, 494, 960 B1 (2002).

[9] Sangeeta D., Macdonald L.S.: Method for removing an aluminide-containing material form a metal substrate, US patent $\mathrm{nr}$ 5, 976, 265 (1999).

[10] Kool L.B., Ruud J.A.: Method for removing oxides and coatings from a substrate, US patent nr 6, 863, $738 \mathrm{~B} 2$ (2005).

[11] Chen K.N., Ngiam S.T.: Method for renewing diffusion coatings on superalloy substrates, US patent nr 6, 355, 116 B1 (2002).

[12] Lucas J.G.: Chemical stripping process, US patent nr 3, 607, 398 (1971).

[13] Fisher R.E., Lada H.: Selective chemical milling of recast surfaces, US patent $\mathrm{nr} 4$, 411, 730 (1982).

[14] Fisher R.E., Lada H., Putnam V.M.: Method and composition for removing nickel aluminide coatings from nickel superalloys, US patent nr 4, 425, 185 (1984).

[15] Wei B., Lipkin D.M., Macdonald L.S.: Electrochemical system and process for stripping metallic coatings, US patent $\mathrm{nr}$ 6, 352, 636 B1 (2002).

[16] Updegrove K., Goodwater F., William F.: Electrochemical stripping of turbine blades, US patent $\mathrm{nr} 6,165,345$ (2000).

\section{SELECTED ASPECTS OF ALUMINIDE COATING REGENERATION ON NICKEL SUPERALLOYS USED FOR PRODUCTION OF TURBINE BLADES}

\section{S u m m a r y}

Selected methods of removing diffusion alluminide coating used for protection of turbine blades were presented in the article. The chemical and electrochemical methods of coatings dissolution used in aerospace industry were described. Three selected removing agents were selected for experimental tests: hydrochloric acid in ethanol solution, sulphuric acid in water as well as mixture of orthophosphoric, acetic and nitride acids. The aluminide coating obtained on IN-100 nickel 
superalloy was used for tests. The conducted research showed that the mixture of orthophosphoric, acetic and nitride acids can dissolve outer-zone of aluminidce coating during 80 min dissolution process. The removing process takes place evenly on the whole surface of sample.

Keywords: aluminide coatings, coatings regeneration, dissolution, turbine blades, superalloys, IN-100

DOI: $10.7862 / \mathrm{rm} .2019 .05$

Otrzymano/received: $12.032019 r$.

Zaakceptowano/accepted: $14.062019 \mathrm{r}$. 
